\title{
Corrosion of AISI316 as containment material for latent heat thermal energy storage systems based on carbonates.
}

\author{
J. Gallardo-González ${ }^{1}$, Mònica Martínez ${ }^{1}$, Camila Barreneche ${ }^{1}$, Ana Inés Fernández ${ }^{1}$, Ming \\ Liu $^{2}$, N.H. Steven Tay ${ }^{2,3}$, Frank Bruno ${ }^{2}$, Mercè Segarra ${ }^{1 *}$ \\ ${ }^{1}$ DIOPMA, Dept. Materials Science and Physical Chemistry, Universitat de Barcelona, Marti i Franquès, \\ 1, 08028 Barcelona, Spain \\ m.segarra@ub.edu \\ ${ }^{2}$ Barbara Hardy Institute, School of Engineering, University of South Australia, Mawson Lakes \\ Boulevard, Mawson Lakes, SA5095 Australia. \\ ${ }^{3}$ Newcastle University Singapore, 172A Ang Mo Kio Avenue 8, \#05-01, SIT Building@Nanyang \\ Polytechnic, Singapore 567739, Singapore \\ ${ }^{*}$ corresponding author
}

\begin{abstract}
Considerable effort has been devoted to the characterization of thermal properties of the different types of materials that can be used as thermal energy storage (TES) media, but scarce literature exists concerning the materials to manufacture the tanks that can be used to contain these storage media. One of the main concerns when selecting the most suitable material for these tanks is its resistance to corrosion due to molten salts that constitute the TES system. Dynamic gravimetric analysis is a newly proposed method for the study of corrosion on metals, which optimizes the standard procedure described by ASTM G1-03. The new technique avoids the direct handling of samples, so more accurate values can be obtained. In this work, the resistance to corrosion of AISI 316 stainless steel samples in contact with commercial grade molten salts of the $\mathrm{Li}_{2} \mathrm{CO}_{3}-\mathrm{Na}_{2} \mathrm{CO}_{3}-$ $\mathrm{K}_{2} \mathrm{CO}_{3}$ system, at $600^{\circ} \mathrm{C}$ for different exposure times, has been determined by using this new methodology. The results show that the initial corrosion rate is lower at higher amounts of lithium carbonate present in the molten salts mixture.
\end{abstract}

\section{Highlights:}

- A new methodology was tested to determine the corrosion rate (CR) by reducing handling.

- The CR on AISI316 in $\mathrm{Li}_{2} \mathrm{CO}_{3}-\mathrm{Na}_{2} \mathrm{CO}_{3}-\mathrm{K}_{2} \mathrm{CO}_{3}$ mixture pairs is up to $2.07 \mathrm{~mm} / \mathrm{yr}$.

- The presence of $\mathrm{Li}_{2} \mathrm{CO}_{3}$ on eutectic mixtures slows down the $\mathrm{CR}$.

- $\mathrm{LiFe}_{5} \mathrm{O}_{8}$ formation significantly increases the corrosion level.

Keywords: thermal energy storage, phase change materials; corrosion; high temperature; carbonates; DGA; ASTM G1-03; AISI 316

\section{Introduction}

One of the most attractive alternatives among all options for energy production from renewable sources are concentrated solar power (CSP) plants whose main feature is to allow the efficient distribution of the electricity they produce [1]. The main principle behind these types of solar power plants is to utilise thermal energy to ultimately produce electricity where heat transfer fluid (HTF) is used to heat the thermal energy storage material (such as a phase change material (PCM)) 
in an indirect system [2]. Phase change latent heat is the energy needed to make a substance or compound change from one phase to another (e.g. solid-liquid). PCMs are those that involve a significant release of energy when changing from one phase to another. They are also called latent heat storage (LHS) media, and typically store heat when melting, while release it when freezing. This capability can be used to store large amounts of energy, especially in those systems where the production of energy is not uniform during the day - such as CSP - thus having peaks and valleys on the amount of produced energy that must be stored in such a way that the overall power distribution system does not become overloaded. As any material subjected to cycle-temperature changes, PCM properties can be altered thus decreasing their performance and lifetime.

The aim of this study is not the material used as PCM, but to study the material used to contain it. When the CSP plant is going to operate for a long time, it is necessary to foresee the possible changes that may occur over time. The containment material suffers the same thermal cycles as LHS, thus introducing changes in dimensions due to the temperature difference (which is related to its thermal expansion coefficient), or inducing creep (an increase in temperature lowers most of the mechanical properties, so that materials suffer a slow and continuous deformation that ends in failure even at stresses below the yield strength). On the other hand, if the material used as LHS is highly corrosive, any other one in contact with it will present, sooner or later, corrosion problems. Plant lifecycle not only depends on the stability of the LHS material but also on the lifetime of the rest of materials involved in its construction. So, one of the main interests of this work is to predict the lifetime of the containment materials by studying their interaction with LHS media during their use. The corrosion of different materials in contact with different TES systems has been randomly studied at low [3] [4] and high temperatures [5]. Regardless, most of them coincide in that stainless steel could be a good candidate [6], while some superalloys, like Inconel, are selected for those salt mixtures that could be more aggressive with their environment such as fluorides. At industrial level, A316L and Inconel 625 are not recommended for service greater than a month when corrosion rates are higher than 1252 and $1184 \mu \mathrm{m} /$ year, respectively [7].

Among all the LHS media, the most prevalent molten salts in use at industrial scale are nitrates and halides [8]. Carbonate mixtures have been chosen for this work as they present good performance at high temperatures. Although there is some data about these systems already used as energy storage media in CSP plants [9], few studies about their electrochemistry [10] [11] have been found, as well as some about their interaction with potential materials for container tanks when used as TES [12][13]. In this work, the chemicals used for TES media are of commercial purity. Therefore, apart from a lower cost than analytical grade chemicals (or pure), they are more affordable and more easily attainable for their implementation in CSP. Nevertheless, they can contain small amounts of impurities that could affect not only the thermal properties of the carbonate mixture (melting point, latent heat) but also the interaction with the containment material. Other studies about corrosion in steel concluded that the impurities typically contained in commercial grades of alkali nitrates have relatively small effects on corrosion of stainless and carbon steels in molten salts prepared from these constituents [14], but no references have been found concerning impurities contained in molten carbonates.

The corrosion of different stainless steels (ferritic and austenitic) has already been studied in ternary molten $\mathrm{Li}_{2} \mathrm{CO}_{3}-\mathrm{Na}_{2} \mathrm{CO}_{3}-\mathrm{K}_{2} \mathrm{CO}_{3}$ (43.5:31.5:25.0 mol\%) mixture at different temperatures $43\left(475-550^{\circ} \mathrm{C}\right)$, using galvanostatic polarization and cyclic voltammetry [15], indicating that the corrosion resistance of the austenitic stainless steel is higher than that of the ferritic steel. The 
scales formed on austenitic steels were found to be multi-layered, whereas those formed on ferritic steels consisted of a single uniform layer [13].

The evaluation of the corrosion rate $(\mathrm{CR})$ is a well-established way to evaluate corrosion suffered by metals. The methodology suggested by the standard procedures ASTM G1-03 [16] and ISO 8407 [17] has been widely used in many fields of research, because this type of research at laboratory scale is a simpler operation that requires few resources. The fundamental principle of the procedure is to remove the oxide layer formed on the metal surface. This allows the determination of the amount of metal lost due to corrosion, which directly relates to the exposure time of the metal, and thus is proportional to the CR. To clean the oxidized surface, the methodology includes a series of cleaning dissolutions that covers the most commonly used metals. However, choosing the right chemical is subjected to background knowledge followed by trial and error in order to establish an effective method for each specific type of metal and oxide. In the standard procedure, cleaning cycles are performed until the sample is completely clean. This involves excessive constant handling and manipulation of the sample, especially when the oxide layer does not dissolve easily; the metal sample is often roughed with sandpaper between each cleaning cycle before being reintroduced into the cleaning solution. The sample is weighed after each cleaning cycle, and its weight plotted against the number of cleaning cycles. The point where the slope changes is taken as the value of the final weight where all the oxide has been removed, and therefore, represents the weight loss of the metal during the corrosion process. Thus, CR can be determined by Eq. 1, where $\Delta w$ is the weight loss, $\rho$ is density of the metal, $S$ is the surface area of the metal, and $t$ is the time of exposure to corrosion.

$$
C R=\frac{\Delta w}{\rho S t}
$$

Eq. 1

Dynamic gravimetric analysis (DGA) was the technique used to perform the corrosion testing in this work. It is a new method developed by University of Barcelona researchers for metal corrosion analysis in which the handling is minimized, so one would expect more precise data. This technique is based on the sample hanging from an analytical balance while it is submerged in the cleaning solution described by Prieto et al. [18]. The main objective of this work is to determine the corrosion rate of $316 \mathrm{SS}$ immersed in different $\mathrm{Li}_{2} \mathrm{CO}_{3}-\mathrm{Na}_{2} \mathrm{CO}_{3}-\mathrm{K}_{2} \mathrm{CO}_{3}$ molten mixtures at $600^{\circ} \mathrm{C}$ for different times, using this new technique.

\section{Experimental procedure}

\subsection{Samples preparation}

A stainless steel series AISI 316, whose main components and properties are presented in Table $\mathbf{1}$, was used to study its corrosion rate in molten carbonates.

\section{Table 1}

Composition of AISI 316 stainless steel.

\begin{tabular}{cccccccccc}
\hline Element & $\mathbf{C}$ & $\mathbf{C r}$ & Mo & Ni & Si (max.) & Mn (max) & P (max) & S (max) & Fe \\
\hline wt \% & 0.07 & $17-18.5$ & $2-2.5$ & $10.5-13.5$ & 1.0 & 2.0 & 0.045 & 0.030 & Balance \\
\hline
\end{tabular}


The metal samples were prepared as follows: they were firstly ground using increasingly finest grades of abrasive paper to remove any metal oxide layers adhered on the surface, and further polished using diamond suspensions in decreasing size $(6$ and $1 \mu \mathrm{m})$, in order to obtain a smooth surface, and followed by cleaning in an acetone ultrasound bath. The plates were then weighed and dimensions were recorded, although they had been cut in such a way to achieve similar areas. Approximate dimensions were $40 \mathrm{~mm}$ x $20 \mathrm{~mm}$ x $30 \mathrm{~mm}$. Two replicates of each sample were tested: one to determine the corrosion rate by DGA, and the other to be observed by SEM.

8 Thermodynamic calculations using FactSage $(\mathcal{C}$ with Phase Diagram module [19] had been done 9 to determine the conditions for multiphase and multicomponent equilibrium. FactSage $\odot$ consists of a series of information, database, calculation and manipulation modules that access various pure substances and solution databases, and Phase Diagram module allows to calculate and plot multicomponent phase diagram sections. The calculation of the phase diagram salt-liquid projection, obtained with this software, for the $\mathrm{Li}_{2} \mathrm{CO}_{3}-\mathrm{Na}_{2} \mathrm{CO}_{3}-\mathrm{K}_{2} \mathrm{CO}_{3}$ system at atmospheric pressure, is shown in Fig. 1, from which some invariant points, related to different mixtures of sodium, lithium and potassium carbonates, can be identified, with different melting points (red circles) as summarized in Table 2.

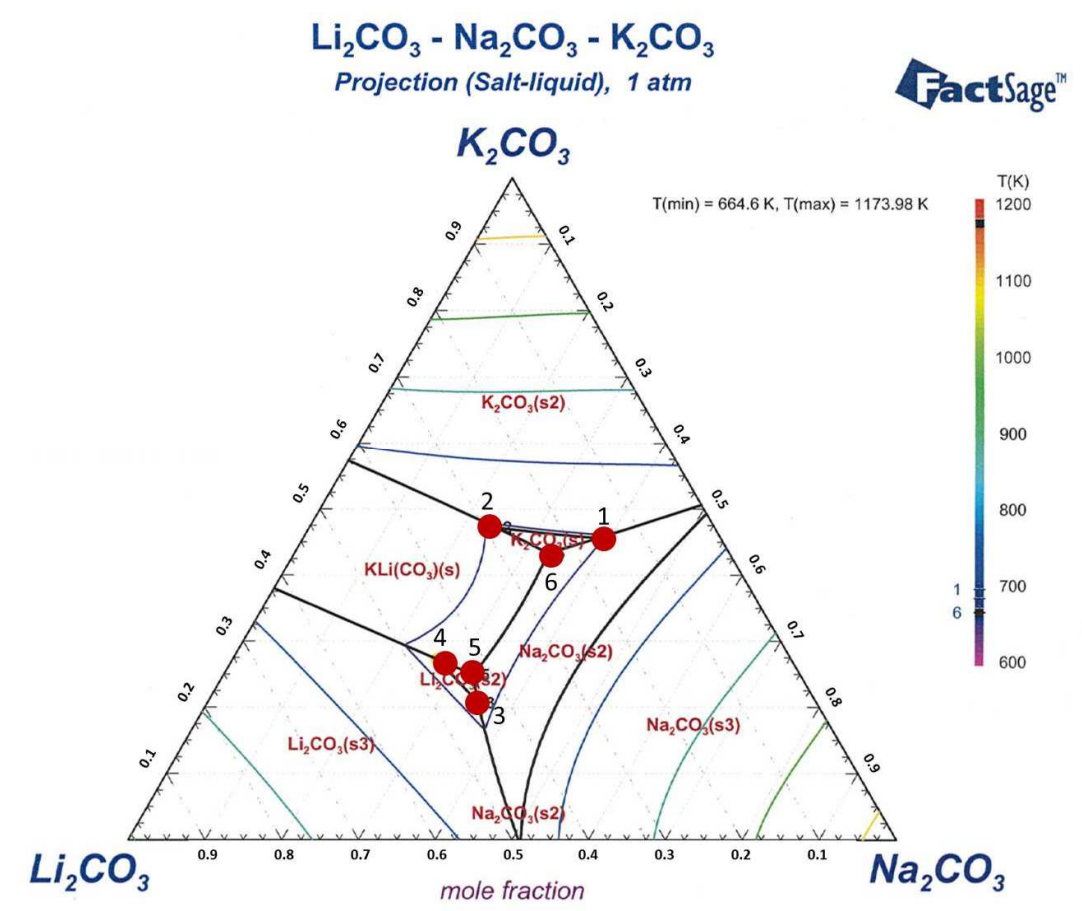


Table 2

2 Projection (salt-liquid) at 1 atm of the system $\mathrm{Li}_{2} \mathrm{CO}_{3}-\mathrm{Na}_{2} \mathrm{CO}_{3}-\mathrm{K}_{2} \mathrm{CO}_{3}$ obtained by FactSage ${ }^{\odot}$

3 with Phase Diagram module software.

\begin{tabular}{|c|c|c|c|c|c|c|c|}
\hline \multirow{2}{*}{ Intersection point } & \multicolumn{3}{|c|}{ Molar fraction } & \multicolumn{3}{|c|}{ wt\% } & \multirow{2}{*}{$\mathrm{T}_{\mathrm{m}}\left({ }^{\circ} \mathrm{C}\right)$} \\
\hline & $\mathrm{Li}_{2} \mathrm{CO}_{3}$ & $\mathrm{Na}_{2} \mathrm{CO}_{3}$ & $\mathrm{~K}_{2} \mathrm{CO}_{3}$ & $\mathrm{Li}_{2} \mathrm{CO}_{3}$ & $\mathrm{Na}_{2} \mathrm{CO}_{3}$ & $\mathrm{~K}_{2} \mathrm{CO}_{3}$ & \\
\hline 1 (PCM1) & 0.15966 & 0.38437 & 0.45597 & 10.2 & 35.3 & 54.5 & 421.9 \\
\hline 2 & 0.28582 & 0.24185 & 0.47232 & 18.9 & 22.9 & 58.3 & 421.9 \\
\hline 3 (PCM3) & 0.44018 & 0.35289 & 0.20693 & 33.0 & 38.0 & 29.0 & 410.0 \\
\hline 4 & 0.46039 & 0.26790 & 0.27171 & 34.0 & 28.4 & 37.6 & 410.0 \\
\hline 5 & 0.42545 & 0.32498 & 0.24956 & 31.3 & 34.3 & 34.4 & 392.5 \\
\hline 6 (PCM2) & 0.23597 & 0.33074 & 0.43328 & 15.5 & 31.2 & 53.3 & 391.5 \\
\hline
\end{tabular}

4 The cleaned stainless steel plates were immersed in the three mixtures of alkali metal carbonates,

$5 \mathrm{Li}_{2} \mathrm{CO}_{3}-\mathrm{Na}_{2} \mathrm{CO}_{3}-\mathrm{K}_{2} \mathrm{CO}_{3}$, that were named PCM1, PCM2 and PCM3, according to the eutectics 1,

66 and 3, respectively. The carbonates used in this study are of commercial grade, so all of them

7 have a minimum purity of $99.0 \mathrm{wt} \%$, being their main contained impurities summarized in Table

83.

9 Table 3

10 Main impurities and composition of each carbonate used in this study.

\begin{tabular}{|c|c|c|c|c|c|}
\hline \multirow{2}{*}{\multicolumn{2}{|c|}{$\begin{array}{l}\text { Potassium carbonate } \\
\text { Analytical Grade ACS } \\
\text { (supplier: ACROS Organics) }\end{array}$}} & \multirow{2}{*}{\multicolumn{2}{|c|}{$\begin{array}{l}\text { Sodium carbonate anhydrous } \\
\text { Analytical Grade } \\
\text { (supplier: Labkem) }\end{array}$}} & \multirow{2}{*}{\multicolumn{2}{|c|}{$\begin{array}{l}\text { Lithium carbonate } \\
\text { GPR Reactpur grade } \\
\text { (supplier: VWR Chemicals-Prolabo) }\end{array}$}} \\
\hline & & & & & \\
\hline Mol. mass ( $\left.\mathrm{g} \mathrm{mol}^{-1}\right)$ & 138.21 & Mol. mass $\left(\mathrm{g} \mathrm{mol}^{-1}\right)$ & 105.99 & Mol. mass ( $\left.\mathrm{g} \mathrm{mol}^{-1}\right)$ & 73.89 \\
\hline Purity (\%) & $\geq 99.0$ & Purity (\%) & $99.5-100$ & Purity (\%) & $>99.0$ \\
\hline $\mathbf{N}(\%)$ & $\leq 0.001$ & $\mathrm{Cl}^{-}(\%)$ & $\leq 0.003$ & $\mathrm{Cl}(\%)$ & $\leq 0.02$ \\
\hline $\mathrm{Cl}^{-}+\mathrm{ClO}_{3}^{-}(\%)$ & $\leq 0.002$ & $\mathrm{SO}_{4}(\%)$ & $\leq 0.003$ & $\mathrm{SO}_{4}(\%)$ & $\leq 0.05$ \\
\hline $\mathrm{PO}_{4}(\%)$ & $\leq 0.001$ & As $(\%)$ & $\leq 0.003$ & $\mathrm{Ca}+\mathrm{Mg}(\%)$ & $\leq 0.04$ \\
\hline $\mathrm{SiO}_{2}(\%)$ & $\leq 0.004$ & $\mathrm{Fe}(\%)$ & $\leq 3 \cdot 10^{-4}$ & $\mathrm{Fe}(\%)$ & $\leq 0.002$ \\
\hline $\mathrm{SO}_{4}(\%)$ & $\leq 0.004$ & $\mathrm{Hg}(\%)$ & $\leq 10^{-4}$ & Heavy metals (as Pb) (\%) & $\leq 0.002$ \\
\hline As $(\%)$ & $\leq 5 \cdot 10^{-5}$ & $\mathrm{~Pb}(\%)$ & $\leq 2 \cdot 10^{-4}$ & & \\
\hline $\mathrm{Ca}+\operatorname{Mg}(\%)$ & $\leq 0.008$ & $\mathrm{H}_{2} \mathrm{O}(\%)$ & $\leq 0.10$ & & \\
\hline $\mathrm{Cu}(\%)$ & $\leq 5 \cdot 10^{-4}$ & & & & \\
\hline $\mathrm{Fe}(\%)$ & $\leq 0.001$ & & & & \\
\hline
\end{tabular}

Thermophysical properties of the three carbonate mixtures have been determined by differential scanning calorimetry (DSC 822-e, Mettler Toledo), with $40 \mu \mathrm{L}$ aluminium crucibles, under $\mathrm{N}_{2}$ atmosphere flow of $50 \mathrm{~mL} \cdot \mathrm{min}^{-1}$. The regular heating/cooling rate was $0.5{ }^{\circ} \mathrm{C} \cdot \mathrm{min}^{-1}$ applied between $350-500{ }^{\circ} \mathrm{C}$. Fig. 2 shows the obtained results, summarized in Table 4. 

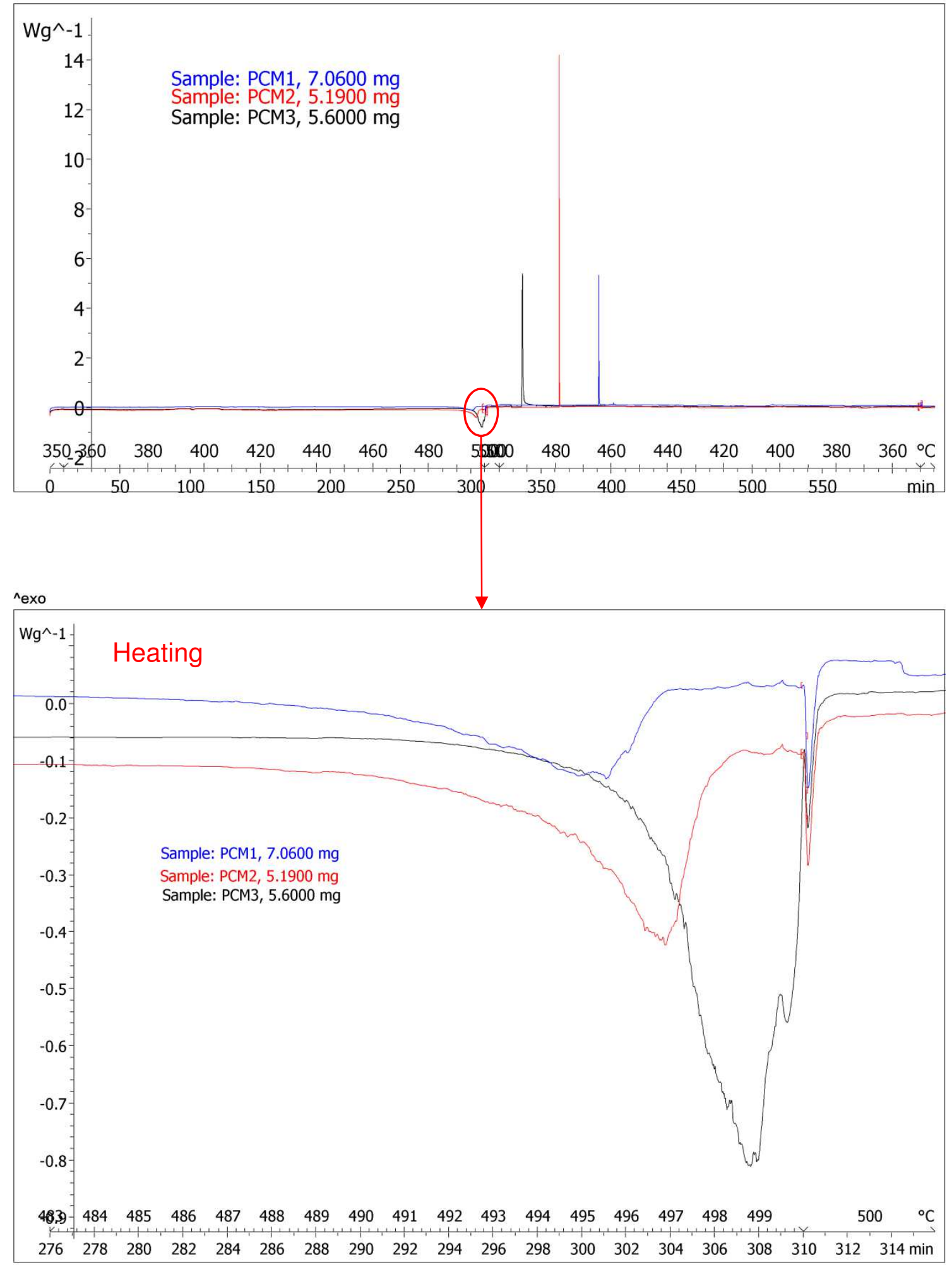

Fig. 2. DSC for the three carbonate mixtures used in this work and magnification of the heating curves.

6 The phase change temperatures of the PCMs under study are similar but the phase change 7 enthalpy is higher for PCM3, which makes it the most suitable PCM candidate. 
2 Results obtained from DSC analysis.

\begin{tabular}{ccc}
\hline Sample & Latent heat $\left(\mathbf{J} \cdot \mathbf{g}^{-1}\right)$ & Phase change peak temperature $\left({ }^{\circ} \mathbf{C}\right)$ \\
\hline PCM1 & 152 & 467.3 \\
PCM2 & 128 & 484.1 \\
PCM3 & 286 & 494.0 \\
\hline
\end{tabular}

\subsection{Dynamic gravimetric analysis (DGA)}

Corrosion tests were carried out in a furnace, with three alumina crucibles $(110 \mathrm{~mL}$, with $50 \mathrm{~mm}$ diameter), each one containing two coupons immersed in a molten carbonate mixture at $600^{\circ} \mathrm{C}$ during different exposure times of 1,3, 7, 15, and 30 days. The fourth alumina crucible containing PCM1 had a thermocouple placed at the centre of the crucible to ensure that all the mixtures achieve the target temperature. Heat treatment was performed at $600{ }^{\circ} \mathrm{C}$, that is above the melting temperature of the three $\mathrm{PCM}$ eutectics, and also in the operating temperature range of a thermal energy storage tank in a CSP plant $\left(350-650^{\circ} \mathrm{C}\right)[20]$. Once the heat treatment was completed, the samples were removed from the crucibles and allowed to cool in the air.

To remove any salts that remained adhered to the surface, the metal plates were submerged in $10 \% \mathrm{v} / \mathrm{v} \mathrm{H}_{2} \mathrm{SO}_{4}$ in order to neutralize the carbonate salts. Sulphuric acid at low concentrations also makes the oxide layer become less compact and thus facilitates the oxide decaling process without removing the corrosion layer itself [21].

Following the DGA procedure [18][22], the thermal treatments coupons were hung from an analytical balance (Ohaus Explorer) with an accuracy of $\pm 0.1 \mathrm{mg}$, and submerged in the cleaning solution for 50 minutes, allowing the dissolution of the scales formed on the sample. This time was experimentally determined to ensure that the oxide layer was completely removed. The solution used to determine the corrosion rate was directly taken from the ASTM standard G1-03, whose composition was: $100 \mathrm{ml} 69 \%$ v/v $\mathrm{HNO}_{3}+20 \mathrm{ml} 48 \% \mathrm{v} / \mathrm{v} \mathrm{HF}+$ distilled water up to $1 \mathrm{~L}$. During this time, the analytical balance was connected to a computer with the software RealTerm: Serial Capture Program 2.0.0.43, which recorded the weight every second, hence providing a real-time picture of the decaling process. Finally, the samples were washed with distilled water, dried with absorbent paper, and weighed. From the data captured by the software, a curve of weight loss versus time can be depicted. This curve depends on the amount of oxide formed on the surface of the metal, and therefore, on the heat treatment applied to the plate. Although the plates were cut as precisely as possible, they were not identical in weight and surface area. Thus for comparative purposes, the weight loss per unit area is calculated.

\section{Results and discussion}

\subsection{Corrosion rates}

Fig. 3 shows the DGA results (weight loss per unit area versus time) for the stainless steel plates SS4, SS5 and SS6 (1 day immersion in PCM1, PCM2 and PCM3, respectively). 


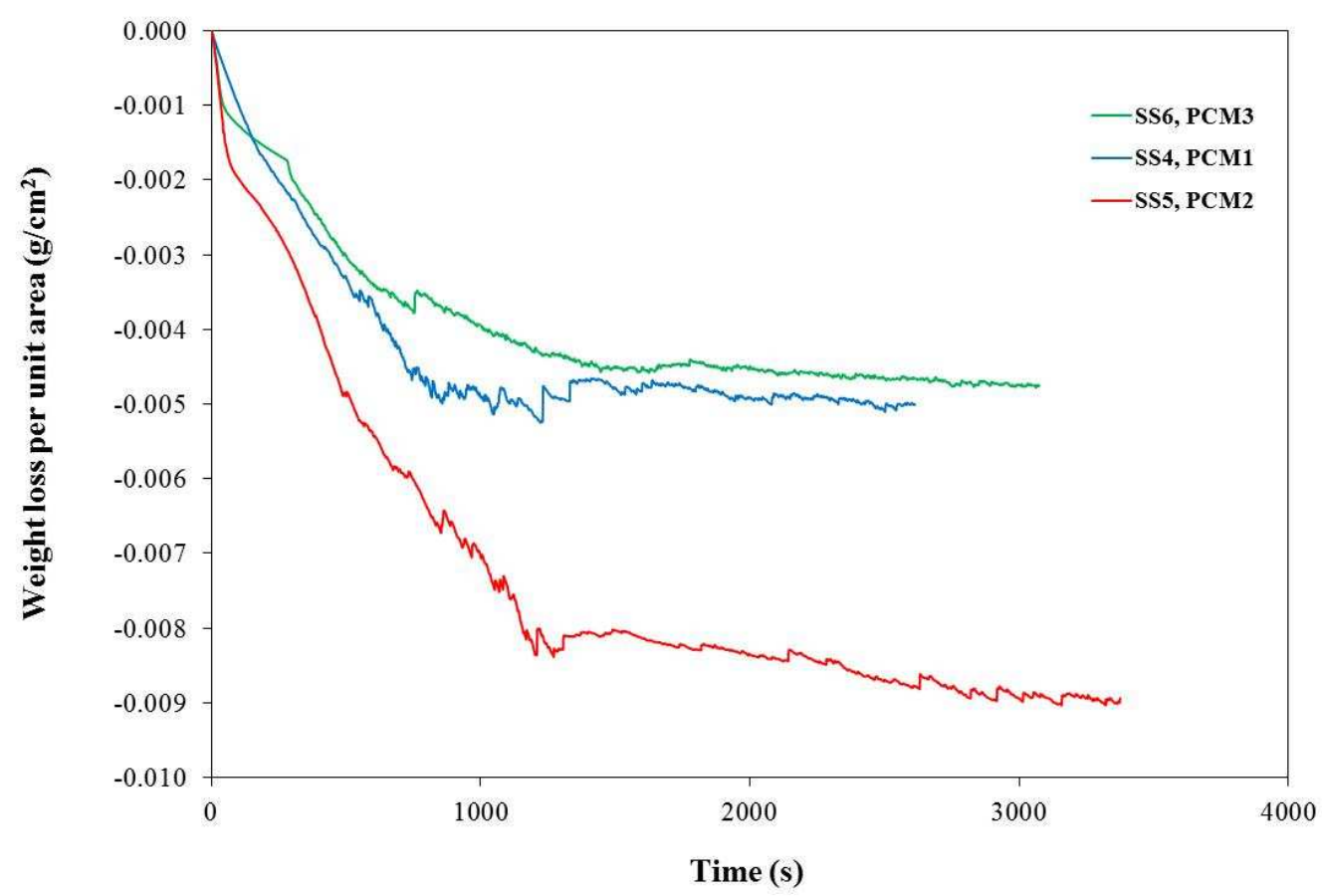

2 Fig. 3. DGA results for samples immersed in PCM1 (SS4), PCM2 (SS5), and PCM3 (SS6) for 1 day at $600^{\circ} \mathrm{C}$.

4 A change in the slope of the curves can be observed in Fig. 3, thus indicating that there is a change 5 in the mechanism of scales dissolution. The first part of the graph (at lower times) can be related 6 to the dissolution of the scale, reaching a maximum at which all the scale has been dissolved.

7 After approximately 1000s (depending on the PCM), there is a change in the slope of the curve 8 (the rate at which the weight per unit area decreases is smaller) thus indicating that the steel 9 sample is dissolving. From the intersection of the two slopes of both behaviours, the amount of 10 formed oxide can be determined.

11 In the case of the SS6 sample, which was immersed in the PCM3, with higher content of lithium 12 carbonate (44\%), its curve has a lower weight loss profile than the others (those immersed in 13 PCM1 and PCM2 with lower $\mathrm{Li}_{2} \mathrm{CO}_{3}$ contents, $16 \%$ and $24 \%$, respectively), thus indicating that 14 its corrosion rate is lower, with PCM1 and PCM2 appearing to be the most corrosive mixtures. 15 For the rest of exposure times, the trend was found to be similar.

16 Fig. 4 shows the weight loss per unit area (expressed in $\mathrm{mg} / \mathrm{cm}^{2}$ of metal loss) determined from 17 DGA plots, against the exposure time during which the thermal treatment at $600^{\circ} \mathrm{C}$ was 18 performed. After 15 days of exposure time (360 hours), weight loss seems to stabilize and remain more or less the same for further exposure times to PCM1 and PCM2. In the case of PCM3, after 30 days (720 hours) the weight loss reaches an asymptotic behaviour with time, slightly higher than for the other PCMs, all in the range of $20-27 \mathrm{mg} / \mathrm{cm}^{2}$. 


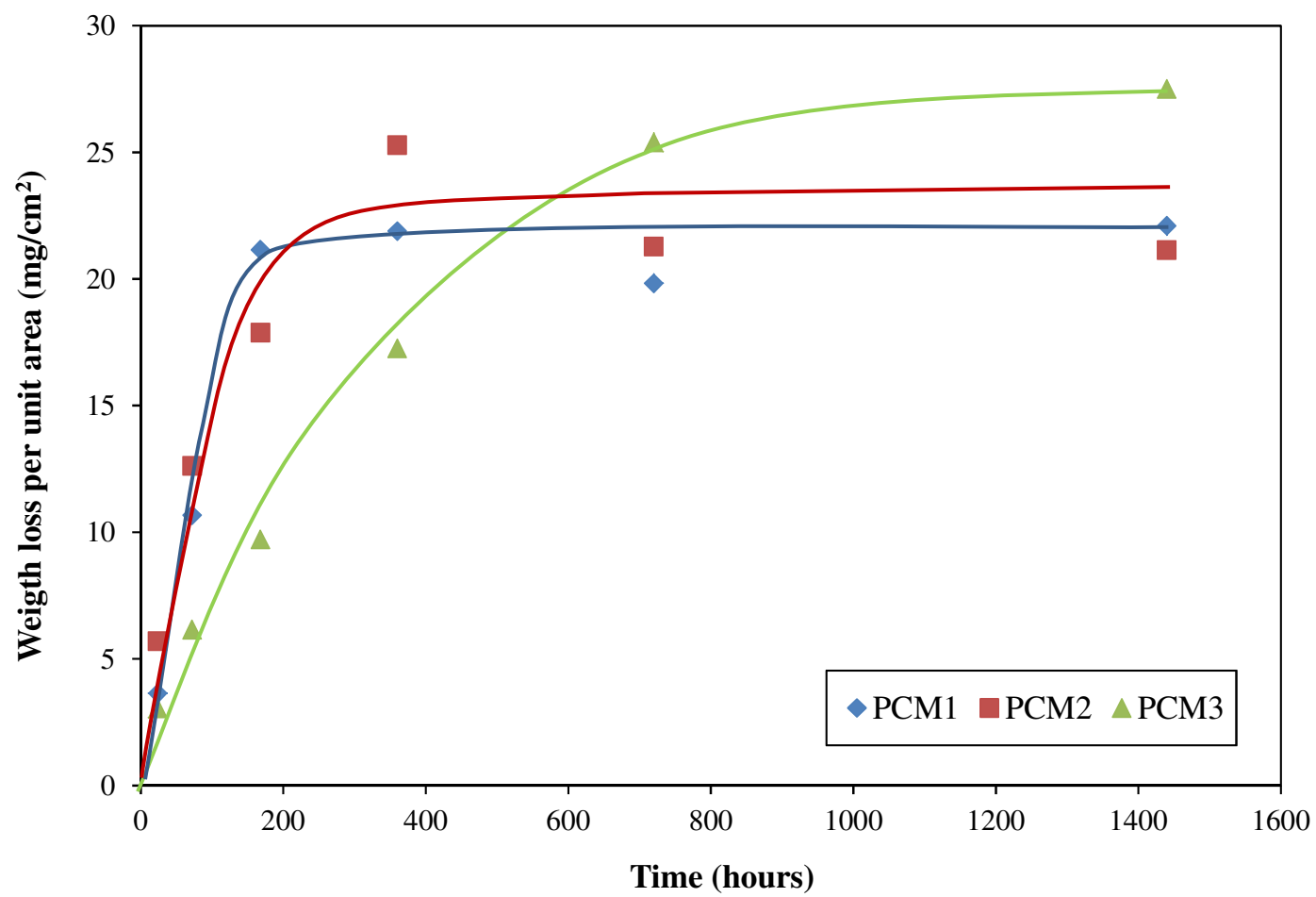

Fig. 4. Weight loss per unit area vs. time for each PCM mixture.

3 The corrosion rate corresponds to the slope of the line obtained by representing the metal loss 4 versus time (Fig. 4) using Eq. 1, giving a final output of $\mathrm{mm} /$ year of metal loss, as expressed in 5 the International System. When this plot is not linear (parabolic or logarithmic, as it is the case), 6 it indicates that the metal is oxidized very rapidly at the start but after some time of exposure the 7 rate decreases to a very low value. Therefore, corrosion rate is changing with time, reaching a 8 maximum value at the initial times, and a constant value (lower) at the end.

9 The initial corrosion rates (which could be considered as estimates of the maximum corrosion 10 rates) for each carbonate mixture could be calculated from the slope of the graph for the first 11 points. They are summarized in Table 5 together with the minimum and constant values obtained at higher times. It can be observed that the corrosion rate for the carbonate mixture with higher lithium carbonate content is lower as compared to the other PCMs.

\section{Table 5}

Initial and minimum corrosion rates for each studied carbonate mixture.

\begin{tabular}{lcc}
\hline Carbonate mixture & Initial corrosion rate $(\mathrm{mm} / \mathrm{year})$ & Minimum corrosion rate $(\mathrm{mm} / \mathrm{year})$ \\
\hline PCM1 & 1.71 & 0.40 \\
PCM2 & 2.07 & 0.32 \\
PCM3 & 1.03 & 0.22 \\
\hline
\end{tabular}

No reference was found in which a value for the corrosion rate of AISI 316 steel in contact with the same salt compositions and at the same temperature studied in this work is reported. For comparison purposes of the range of values, we can indicate the work published by Gomez-Vidal et al. [23] in which 347 stainless steel (very similar to 316 but with a much lower molybdenum content of $0.4 \%$ ) in contact with eutectics of $\mathrm{Na}$ and $\mathrm{K}$ carbonates at $750{ }^{\circ} \mathrm{C}$, is reported with a corrosion rate of $2360 \pm 390 \mu \mathrm{m} /$ year. 
As PCM3 contains about twice the lithium carbonate content with the potassium carbonate content halved with respect to the other PCM mixtures, and the sodium carbonate content of the three PCMs remained fairly constant, it can be suggested that the corrosion rate could have a relation to the content of $\mathrm{Li}_{2} \mathrm{CO}_{3}$, decreasing as this carbonate content increases.

\subsection{Compositional and morphological analysis}

In order to determine the crystalline phases of the corrosion products, scales formed on the surface of plates exposed for 1 day to each PCM mixture were analyzed by X-ray diffraction (XRD) using a Bragg-Brentano Siemens D-500 powder diffractometer with $\mathrm{CuK}$ radiation. The results are shown in Fig. 5.
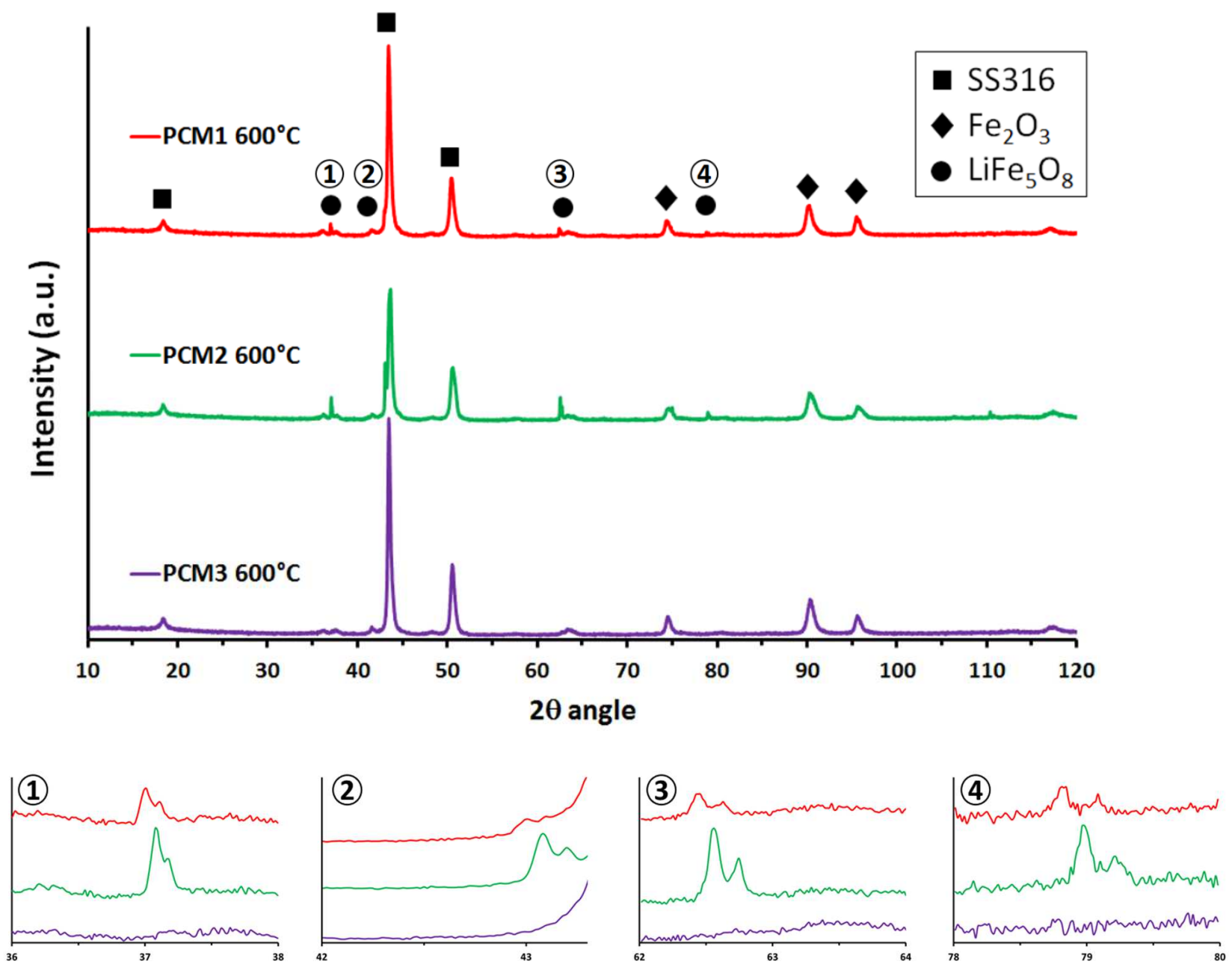

Fig. 5. XRD results for samples exposed to PCM1, PCM2 and PCM3 for 1 day at $600^{\circ} \mathrm{C}$, with enlarged $\mathrm{LiFe}_{5} \mathrm{O}_{8}$ peaks.

As seen in the XRD diffractograms, $\mathrm{LiFe}_{5} \mathrm{O}_{8}$ is present in samples treated with the PCM1 and PCM2, whereas it is not detected in scales formed on the surface of the plate immersed in PCM3. Indeed, the intensity of the peaks decreases from PCM2 to PCM1. This could confirm the formation of a layer of $\mathrm{LiFe}_{5} \mathrm{O}_{8}$ which does not offer protection from corrosion and may in fact promote the corrosion process, as the presence of this compound is consistent with the corrosive nature of the PCMs: PCM2> PCM1> PCM3. It has been previously reported that below $580^{\circ} \mathrm{C}$ porous $\mathrm{LiFe}_{5} \mathrm{O}_{8}$ is formed [12] thus offering little protection to the base metal. 
Scales were also examined by a Leica Cambridge Stereoscan S360 scanning electron microscopy (SEM) equipped with energy dispersive X-ray (EDX) microanalysis. Previously, the specimens were embedded in epoxy resin, cut in half and the cross sections were polished. Before SEM observation samples were carbon coated. Fig. $\mathbf{6}$ and $\mathbf{7}$ show some of these images. Using this technique the morphology of the oxide layer can be observed, as well as an approximation to its composition. This multi-layered structure is in accordance with other works [13] [24].
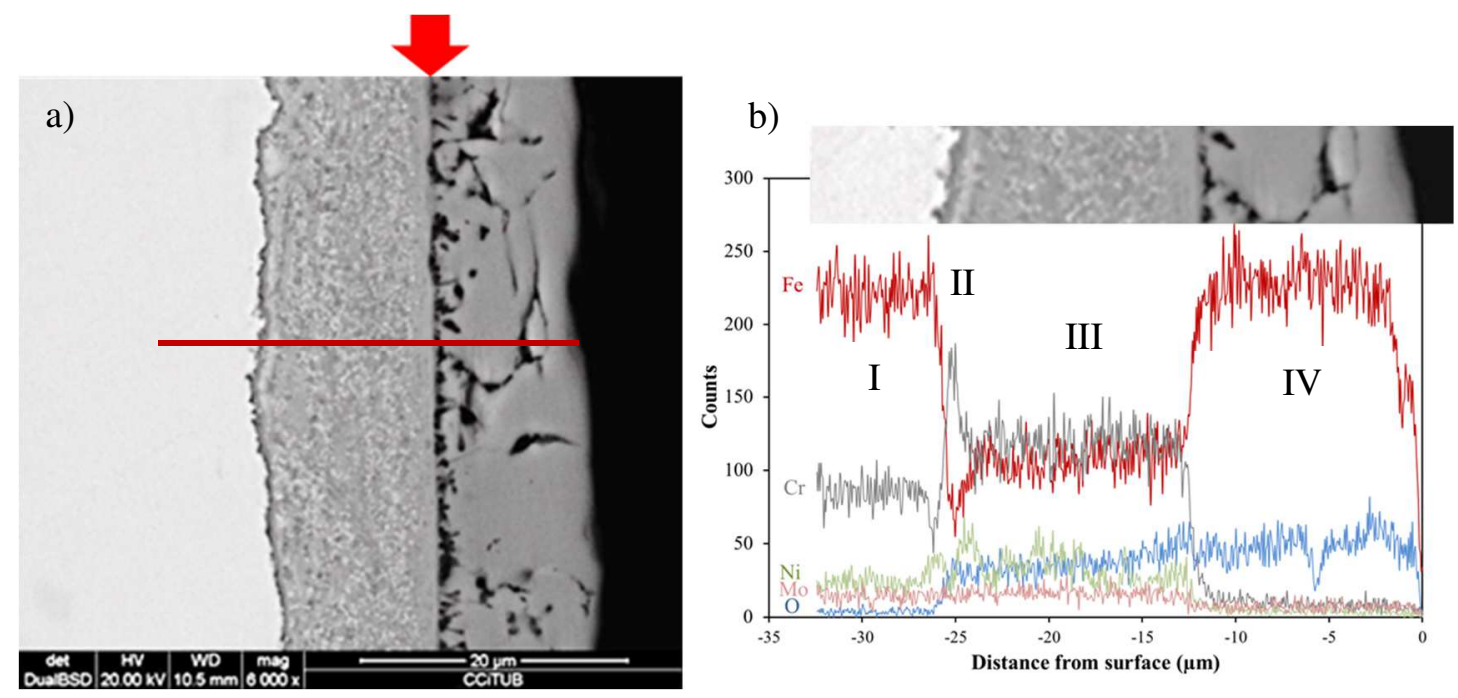

Fig. 6. a) SEM image for the plate immersed for 7 days at $600^{\circ} \mathrm{C}$ in PCM3 and b) composition lines for $\mathrm{Fe}, \mathrm{Cr}, \mathrm{Ni}, \mathrm{Mo}$ and $\mathrm{O}$, obtained by EDS at the red line in a).

It can be observed that the outer layer (on the right in Figure 6a, zone IV in Figure 6b) is mainly composed by iron (garnet line) and oxygen (blue line). In between this layer and the original steel (zone I) there are two other layers in which the amount of iron decreases while increasing the amount of chromium (grey line) in zone III, which is maximum in zone II, finding some oxygen and a non-homogeneous amount of nickel (green line). This indicates that iron goes out of the sample when it is oxidized, leaving a first layer rich in chromium and oxygen (zone II) and rich in chromium, nickel and oxygen (zone III) (the original surface - indicated with a red arrow remains unchanged between the iron oxide layer and that of chromium and nickel oxides). By energy-dispersive X-ray spectroscopy (EDS), Li cannot be detected as its atomic weight is too low, and this technique is incapable of detecting elements lighter than carbon.
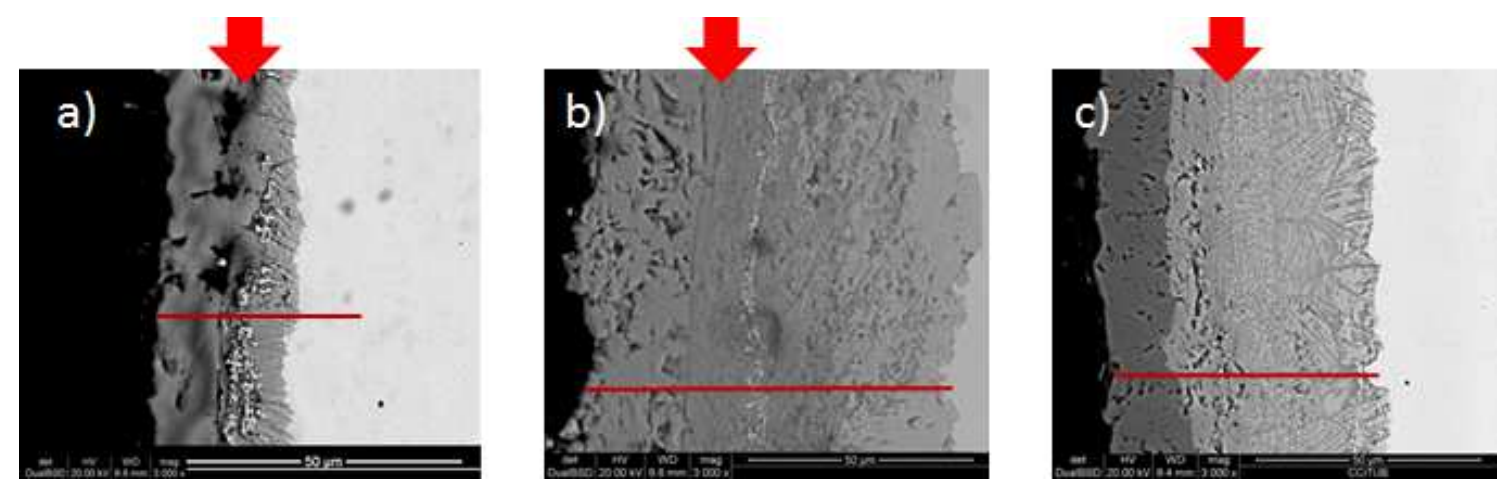

Fig. 7. SEM images for plates immersed for 30 days at $600^{\circ} \mathrm{C}$ in a) PCM1, b) PCM2, and c) PCM3. Red arrows indicate the original surface. 


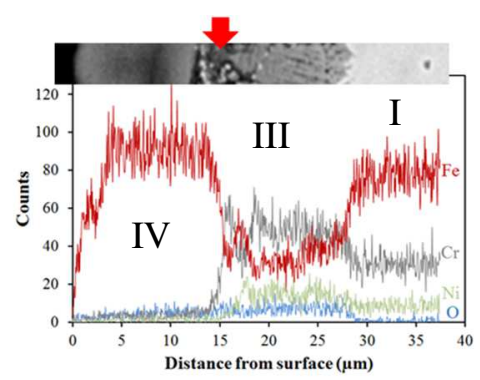

a)

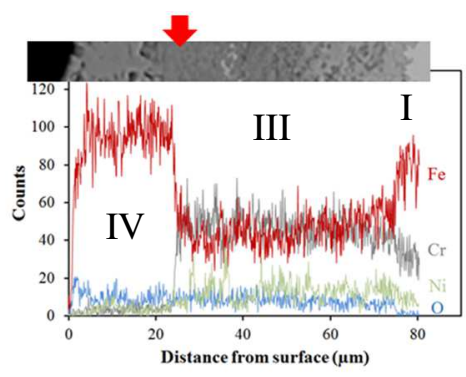

b)

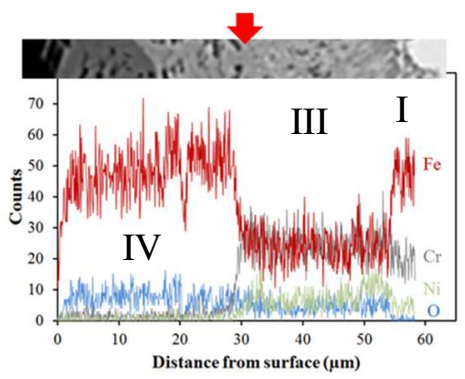

c)

Fig. 8. Composition lines for $\mathrm{Fe}, \mathrm{Cr}$, $\mathrm{Ni}$ and $\mathrm{O}$, obtained by EDS at the red lines in Fig. 7, a) PCM1, b) PCM2, and c) PCM3.

As can be seen in Fig. 8, after 30 days of corrosion, the zone II, enriched in chromium (observed after 7 days of corrosion in PCM3, Fig 6) cannot be differentiated from zone III in any of the tested PCMs. The thicknesses of zone III and zone IV are different depending on the PCM composition, thus indicating that the corroded amount of steel is also different.

The thickness of the iron oxide layer observed in SEM images (zone IV in previous figures) could not be representative of the formed oxide, as it can be broken or partially removed during handling and preparing the sample for SEM observation. This iron has emerged from the layer that becomes rich in chromium and nickel (zone III). So the thickness of this inner layer could be a first step to determine the amount of corroded steel if the composition for each sample could be determined. Unfortunately, with this technique it was not possible to determine the exact composition of this layer.

\section{Conclusions}

The corrosion rate of different mixtures of $\mathrm{Li}_{2} \mathrm{CO}_{3}-\mathrm{Na}_{2} \mathrm{CO}_{3}-\mathrm{K}_{2} \mathrm{CO}_{3}$ on AISI316 stainless steel at $600^{\circ} \mathrm{C}$ has been experimentally determined. The studied eutectic salts can work within the operating temperature of solar concentration power plants and, therefore, are candidates to be used as materials for thermal energy storage. The corrosion rate was studied using the new methodology, DGA, and results were obtained for the three carbonate mixtures, PCM1, PCM2 and PCM3, which showed initial corrosion rates of 1.71, 2.07 and $1.03 \mathrm{~mm} /$ year, respectively. It seems that the high content of $\mathrm{Li}_{2} \mathrm{CO}_{3}$ slows down the initial metal corrosion process but for higher times $(1440 \mathrm{~h})$ corrosion rates are quite similar. Using XRD, the oxide layer formed on the surface of each of the metals immersed in the three different salt compositions was characterized. The presence of $\mathrm{LiFe}_{5} \mathrm{O}_{8}$ on the plates exposed to PCM1 and PCM2, with lower amounts of $\mathrm{Li}_{2} \mathrm{CO}_{3}$, indicates that this could be the key product which causes an increased level of corrosion. However, further studies and characterization techniques are required to help to fully understand the actual mechanism of the process, where the formation of the lithium ferrite seem to cause an increase in the corrosion rate.

\section{Acknowledgements}

The authors wish to thank the "Generalitat de Catalunya" for giving quality accreditation to the DIOPMA (SGR2014-1543) research group. They also want to thank the European Union's 
1 Seventh Framework Programme (FP7/2007-2013) that under the Grant Agreement PIRSES-GA2 2013-610692 (INNOSTORAGE) has facilitated the development of this research activity and for 3 the European Union's Horizon 2020 research and innovation program under grant agreement No 4657466 (INPATH-TES). This work has also been partially funded by the Spanish government 5 (ENE2015-64117-C5-2-R (MINECO/FEDER)). Dr. Camila Barreneche would like to thank 6 Ministerio de Economia y Competitividad de España for Grant Juan de la Cierva FJCI-2014722886.

8 This research was also performed as part of the Australian Solar Thermal Research Initiative 9 (ASTRI), a project supported by the Australian Government, through the Australian Renewable 10 Energy Agency (ARENA). The authors also acknowledge the South Australian Department of 11 State Development who have funded this research through the Premier's Research Industry Fund 12 - International Research Grant Program (IRGP 33). 
[1] A. Gil, M. Medrano, I. Martorell, A. Lazaro, P. Dolado, B. Zalba, et al., State of the art on high temperature thermal energy storage for power generation. Part 1-Concepts, materials and modellization, Renew. Sustain. Energy Rev. 14 (2010) 31-55. doi:10.1016/j.rser.2009.07.035.

[2] Q. Mao, L. Zhang, H. Wu, X. Liu, Design and calculation of a new storage tank for concentrating solar power plant, Energy Convers. Manag. 100 (2015) 414-418. doi:10.1016/j.enconman.2015.05.022.

[3] L.F. Cabeza, J. Illa, J. Roca, F. Badia, H. Mehling, S. Hiebler, et al., Immersion corrosion tests on metal-salt hydrate pairs used for latent heat storage in the 32 to $36^{\circ} \mathrm{C}$ temperature range, Mater. Corros. 52 (2001) 140-146. doi:10.1002/1521-4176(200102)52:2<140::AID$\mathrm{MACO} 140>3.0 . \mathrm{CO} ; 2-\mathrm{R}$.

[4] F.C. Porisini, Salt hydrates used for latent heat storage: Corrosion of metals and reliability of thermal performance, Sol. Energy. 41 (1988) 193-197. doi:10.1016/0038-092X(88)90136-3.

[5] D. Heine, F. Heess, M. Groll, Physical and chemical properties of latent heat storage materials, in: A.S. et al. Strub (Ed.), New Ways to Save Energy, ECSC, EEC, EAEC, Brussels and Luxemburg, 1980: pp. 536-545.

[6] M.M. Kenisarin, High-temperature phase change materials for thermal energy storage, Renew. Sustain. Energy Rev. 14 (2010) 955-970. doi:10.1016/j.rser.2009.11.011.

[7] F.J. Ruiz-Cabañas, A. Jové, C. Prieto, V. Madina, A.I. Fernández, L.F. Cabeza, Materials selection of steam-phase change material (PCM) heat exchanger for thermal energy storage systems in direct steam generation facilities, Sol. Energy Mater. Sol. Cells. 159 (2017) 526-535. doi:10.1016/j.solmat.2016.10.010.

[8] H.C. Maru, J.F. Dullea, A. Kardas, L. Paul, Molten Salt Thermal Energy Storage Systems, 1978. doi:http://allen.neep.wisc.edu/shell/index.php/salts.

[9] M. Liu, W. Saman, F. Bruno, Review on storage materials and thermal performance enhancement techniques for high temperature phase change thermal storage systems, Renew. Sustain. Energy Rev. 16 (2012) 2118-2132. doi:10.1016/j.rser.2012.01.020.

[10] S.D. Cramer, B.S. Covino, eds., Corrosion by Molten Nitrates, Nitrites, and Fluorides, in: ASM Handb. Vol. 13A, Corros. Fundam. Testing, Prot., ASM International, 2003: pp. 124-128.

[11] S.S. Mahmoud, Corrosion and Passivation Behaviours of Iron in Molten Alkali Carbonates, Port. Electrochim. Acta. 23 (2005) 423-436.

[12] A.M. Kruizenga, Corrosion Mechanisms in Chloride and Carbonate Salts, Alburquerque, NM, 2012. http://prod.sandia.gov/techlib/access-control.cgi/2012/127594.pdf.

[13] M. Sarvghad, T.A. Steinberg, G. Will, Corrosion of steel alloys in eutectic $\mathrm{NaCl}+\mathrm{Na} 2 \mathrm{CO} 3$ at $700{ }^{\circ} \mathrm{C}$ and $\mathrm{Li} 2 \mathrm{CO} 3+\mathrm{K} 2 \mathrm{CO} 3+\mathrm{Na} 2 \mathrm{CO} 3$ at $450{ }^{\circ} \mathrm{C}$ for thermal energy storage, Sol. Energy Mater. Sol. Cells. 170 (2017) 48-59. doi:10.1016/j.solmat.2017.05.063.

[14] S.H. Goods, R.W. Bradshaw, Corrosion of Stainless Steels and Carbon Steel by Molten Mixtures of Commercial Nitrate Salts, J. Mater. Eng. Perform. 13 (2004) 78-87. doi:10.1361/10599490417542.

[15] A.A. Attia, S.A. Salih, A.M. Baraka, Corrosion and passivation behaviors of some stainless steel alloys in molten alkali carbonates, Electrochim. Acta. 48 (2002) 113-118. doi:10.1016/S00134686(02)00506-6.

[16] ASTM, ASTM G1-03 : 2011, Standard Practice for Preparing, Cleaning and Evaluating Corrosion Test Specimens., Annu. B. ASTM Stand. (2011). doi:10.1520/G0046-94R05.2.

[17] International Organization for Standardization (ISO), Corrosion of metals and alloys - Removal of corrosion products from corrosion test specimens (ISO 8407:2009), (2009).

[18] C. Prieto, J. Gallardo-gonzález, F.J. Ruiz-cabañas, C. Barreneche, M. Martínez, M. Segarra, et al., Study of corrosion by Dynamic Gravimetric Analysis ( DGA ) methodology . Influence of chloride content in solar salt, Sol. Energy Mater. Sol. Cells. 157 (2016) 526-532. doi:10.1016/j.solmat.2016.07.027.

[19] C. Bale, P. Chartrand, S. Degterov, FactSage thermochemical software and databases, Calphad. 
26 (2002) 189-228. doi:10.1016/S0364-5916(02)00035-4.

[20] K. Vignarooban, X. Xu, A. Arvay, K. Hsu, A.M. Kannan, Heat transfer fluids for concentrating solar power systems - A review, Appl. Energy. 146 (2015) 383-396.

doi:10.1016/j.apenergy.2015.01.125.

[21] International Renewable Energy Agency (IRENA), Concentrating Solar Power, 2012. doi:10.1063/1.2993731.

[22] M. Liu, S. Bell, M. Segarra, N.H. Steven Tay, G. Will, W. Saman, et al., A eutectic salt high temperature phase change material: Thermal stability and corrosion of SS316 with respect to thermal cycling, Sol. Energy Mater. Sol. Cells. 170 (2017) 1-7. doi:10.1016/j.solmat.2017.05.047.

[23] J.C. Gomez-Vidal, J. Noel, J. Weber, Corrosion evaluation of alloys and MCrAlX coatings in molten carbonates for thermal solar applications, Sol. Energy Mater. Sol. Cells. 157 (2016). doi:10.1016/j.solmat.2016.07.029.

[24] M.T. de Miguel, V. Encinas-Sánchez, M.I. Lasanta, G. García-Martín, F.J. Pérez, Corrosion resistance of HR3C to a carbonate molten salt for energy storage applications in CSP plants, Sol. Energy Mater. Sol. Cells. 157 (2016) 966-972. doi:10.1016/j.solmat.2016.08.014. 